\title{
Optimization of Emulsification Process Parameters of Cinnamon Oil Nanoemulsion
}

\author{
Yuliani Aisyah", Sri Haryani $^{\#}$, Novi Safriani ${ }^{\#}$, Nida El Husna ${ }^{\#}$ \\ ${ }^{\#}$ Department of Agricultural Product Technology, University of Syiah Kuala, Darussalam - Banda Aceh, 23111, Indonesia \\ E-mail: yuliani.aisyah@unsyiah.ac.id
}

\begin{abstract}
Cinnamon (Cinnamomum burmannii) is a species of plant that produces essential oil known as cinnamon oil. The cinnamon oil has been used as antibacterial and anti-inflammatory agents. The essential oils are not soluble in water. Therefore, their application into food products is limited. An approach that can be done to overcome this problem is by incorporating essential oils into a nanoemulsion system. This research aimed to optimize the emulsification process of the cinnamon oil nanoemulsion by varying the emulsifying condition, i.e., homogenization speed, time, pressure, and cycles. The physicochemical properties and stability of cinnamon oil nanoemulsion were observed. The homogenization process with a speed of 14000 rpm for 3 minutes produced cinnamon oil emulsion with droplet size $10.40 \mu \mathrm{m}$ and polydisperdibility index (PDI) of 0.901 . The homogenization process at 500 bar using high-pressure homogenizer with three cycles produced cinnamon oil nanoemulsion with droplet size $\pm 117.5 \mathrm{~nm}$ and polydispersibility index (PDI) of 0.123 . The droplet size of nanoemulsion during storage at $4 \pm 2{ }^{\circ} \mathrm{C}, 28 \pm 2{ }^{\circ} \mathrm{C}$, and $40 \pm 2{ }^{\circ} \mathrm{C}$ for three months did not change the droplet size $(\mathbf{P}<0.05)$. The minimum concentration to inhibit $S$. aureus and E.coli was similar for bulk, coarse emulsion and nanoemulsion of cinnamon oil. However, cell count after the two bacteria tested at $37^{\circ} \mathrm{C}$ incubation for 24 hours showed that the highest number of bacterial cells was in bulk cinnamon oil, followed by the coarse emulsion and lowest number of bacterial cells was in cinnamon oil nanoemulsion. This indicates that cinnamon oil nanoemulsion has a higher antibacterial activity than coarse emulsion and bulk cinnamon oil.
\end{abstract}

Keywords — cinnamon oil; nanoemulsion; antibacterial activity; emulsion stability.

\section{INTRODUCTION}

The emulsion is a system consisting of two or more liquids that have polarity differences and can be prepared by dispersing small amounts of liquid into another. The dispersed phase will form large globules which are then broken down using a homogenizer. The emulsion can be categorized into a conventional emulsion, microemulsion, and nanoemulsion-based on the particle size of the dispersed phase, stability and their characteristics [1].

Essential oils are commodities that have great potential in Indonesia. Essential oils which also known as etheric oils are the product of secondary metabolites that generally occur in plants. The essential oil of cinnamon (Cinnamomum burmannii) has been used as antibacterial and antiinflammatory agents. Studies show that the antibacterial effect of cinnamon oil is related to cinnamaldehyde, the major compounds found in this oil [2]-[4]. Essential oils are insoluble in water and have hydrophobic properties so it can enter the fatty parts of the cell membrane of bacteria and mitochondria, disrupting the structure of membrane cell bacteria and make it less permeable [5]. Therefore their application into food products is limited to high-fat food products.

One way to overcome these problems is by incorporating essential oils into nanoemulsion. This method allows the dissolution of the substance that is hydrophobic to the hydrophilic system. Emulsification into nanoemulsion can improve the availability of essential oils because it produces a tiny particle that increases the surface area and solubility rate [6]. Nanoemulsion is thermodynamically stable. Nanoemulsion has a droplet size of $50-500 \mathrm{~nm}$. It is an emulsion system of transparent or translucent dispersion of oil and water that is stabilized by an interfacial film or surfactant and cosurfactant molecules [7]. The surfactants is a substance that serves to decrease the interfacial tension between two immiscible liquids and make them miscible. Surfactants used in preparing o/w nanoemulsions include Tween 80, Tween 20, Span 20, PEG 400 monostearate, Emulphor 620, Softigen 701 and others [8]. Cosurfactants are used if the surfactants themselves alone have not been able to reduce the $\mathrm{o} / \mathrm{w}$ interface tension for the preparing of nanoemulsions. Cosurfactants used in the manufacturing of nanoemulsions such as Lecithin, Polyethylene glycol, Glycerin, Ethanol, Butanol, and others. The cosurfactant 
reduces the interfacial tension by increasing the interface fluidity and entropy of the system [9].

The small droplet size of nanoemulsion leads to the formation of kinetically stable emulsion which prevents sedimentation and creaming during storage [10] and also increases its functional activity [11]. Type of surfactant used is particularly vital because surfactant is immediately needed after droplets are formed during the homogenization process [12]. Surfactants or surface active agents have a hydrophilic group and a lipophilic group so they can stabilize a mixture of oil and water. According to the presence of a hydrophobic group and a hydrophilic group in one molecule causes surfactants to tend to be at the interface. The formation of the interfacial layer is capable of lowering the interfacial energy. The use of surfactant affects the type of the resulting emulsion. A surfactant having a strong polar group will tend to form an oil in water emulsion $(\mathrm{o} / \mathrm{w})$ whereas a surfactant having a robust non-polar group will tend to form water in oil emulsion (w/o) [13]. Tween 80 is a non-ionic surfactant, soluble in water (hydrophilic) and has HLB of 15. This type of surfactant has low toxicity [14] and increases the viscosity of the dispersed phase. Tween 80 can form a thin layer surrounding the droplets and prevent the agglomeration of the dispersed phase so that no precipitation occurs [15].

Previous studies showed that the process of nanoencapsulation improved the antimicrobial activity of essential oils. Donsi et al. [16] investigated the nanoemulsions of a terpene mixture extracted from Melaleuca alternifolia and D-limonene. The terpenes nanocapsules were tested in orange and pear juices, inoculated with $L$. delbrueckii. The addition of low concentration of the nanocapsule terpenes was able to delay the microbial growth $(1.0 \mathrm{~g} / \mathrm{L}$ terpenes $)$ or utterly inactive microorganism (5.0 g/L terpenes) while minimally altering the organoleptic properties of fruit juices.

Ghosh et al. [17] examined the antibacterial activity of sesame oil blended eugenol-loaded nanoemulsion using ultrasonic emulsification process. Nanoemulsion of sesame oil: eugenol is equal to $3: 3$ with $3 \%$ of eugenol concentration exhibited antibacterial activity against Staphylococcus aureus. The result also demonstrated a significant reduction in the heterotrophic bacteria population in orange juice. This research aimed to optimize the emulsification process of the cinnamon oil nanoemulsion by varying the concentration of surfactants and emulsification cycles using high-pressure homogenizer. The resulted nanoemulsions were characterized.

\section{MATERIALS AND METHODS}

\section{A. Materials}

Materials used in this research were the essential oil of cinnamon oil (food grade) from PT. Djasula Wangi, Jakarta, and Tween 80 (polyoxyethylene-20-sorbitan monooleate) (Sigma). The antibacterial test used Staphylococcus aureus, and Escherichia coli isolates, Sterile $\mathrm{NaCl} 0,9 \%$, MuellerHilton Agar (105437 Merck Millipore), Nutrient Agar (105450 Merck Millipore) and ampicillin. This study used analytical grade in testing all chemicals. Purified water was used for the preparation of emulsions. All experiments and analysis were carried out in duplicate.
1) Formulation of Cinnamon Oil Nanoemulsions: The coarse emulsion was prepared by dispersing $15 \%$ of cinnamon oil into the double distilled water and tween 80 as a surfactant. The concentration of tween 80 was $20 \%$ of the cinnamon oil $(\mathrm{w} / \mathrm{v})$. The mixture then homogenized by a high shear homogenizer (IKA T25 digital Ultra Turrax) at $10000 \mathrm{rpm}, 12000 \mathrm{rpm}$, and $14000 \mathrm{rpm}$ for 1 minute, 2 minutes and 3 minutes. The most stable coarse emulsions obtained from a process of $14000 \mathrm{rpm}$ for 3 minutes were then subjected to subsequent homogenization using HighPressure Homogenizer (GEA Niro Soavi Panda Plus) at 100 bars, 300 bars and 500 bars with 1, 2, 3 and 4 cycles. The optimal condition for the subsequent homogenization was achieved at 500 bar and 3 cycles. This condition was furthermore used to observe the effect of emulsifier concentration toward nanoemulsion stability. The concentrations of emulsifier tested were 5\%, $10 \%, 15 \%$, $20 \%$ and $25 \%$ of the weight of cinnamon oil.

2) Characterization of Nanoemulsions: Characterization of nanoemulsions includes measurement of droplet size, polydispersity index (PDI) and zeta potential. The measurement was conducted using Malvern Zetasizer Nano $\mathrm{ZS}$ at $25^{\circ} \mathrm{C}$. The mean droplet diameter and the PDI were determined through light scattering mechanism in a Zetasizer Nano ZS (Malvern Instruments, UK) after emulsion samples had been diluted in double-distilled water for $1 / 10$ of their initial concentration to avoid multiple scattering effects. Droplet sizes were indicated by CZaverage which measured the scattering intensity-weighed mean diameter of the droplets present in an emulsion [12].

3) The Effects of Storage on The Stability Cinnamon Oil Nanoemulsions: The cinnamon oil nanoemulsions stored at 4 $\pm 2{ }^{\circ} \mathrm{C}, 28 \pm 2{ }^{\circ} \mathrm{C}$ and $40 \pm 2{ }^{\circ} \mathrm{C}$ for 90 days. The observation was carried out right after the emulsification process, at the 30th, 60th and 90th days of storage. The parameters evaluated were droplet size, PDI, and zeta potential. The nanoemulsion droplets were also analyzed by Transmission Electron Microscope (TEM, JEOL JEM 1400) to observe the droplets' morphology [17]. For this purpose, two samples were monitored after freshly produced and after storage for 90 days at $4{ }^{\circ} \mathrm{C}$.

\section{B. Methods}

1) Antibacterial Activity Test: Antibacterial activity test was carried out following the method written by KirbyBauer [18]. Inoculations of Staphylococcus aureus and Escherichia coli were conducted by dipping a cotton swab into a test tube containing bacterial culture. Then the cotton swab was scratched three times the petri dish that contained MHA (Mueller Hinton Agar) media. Paper discs are having $6 \mathrm{~mm}$ in diameter (Filter papers 40 Whatman 1440-090) soaked in cinnamon oil for 30 minutes and then drained for 15 minutes. The paper disc was placed on the surface of petri dish which contained MHA and had been inoculated with a bacterial test (Staphylococcus aureus and Escherichia coli). The incubation was done at $37^{\circ} \mathrm{C}$ for 24 hours. The clear zone around the paper disc showed inhibition of bacterial growth. Measurement of a clear zone was done by measuring the diameter of inhibitory zone from left end to the right end area of the clear zone surrounding the paper 
disc. Ampicillin (commercial antibiotics) used as a control in this study.

2) Cell count Analysis: The cell counts analysis of S. aureus and E. coli on bulk cinnamon oil, coarse emulsion, and cinnamon oil nanoemulsion was established by monitoring the surviving cell numbers in inoculated plates after $24 \mathrm{~h}$ of incubating at $37^{\circ} \mathrm{C}$. Each assay included a growth control test sample. Inoculation and enumeration were carried out by the drop plate method of Herigstad et al., [18] with some modifications. Briefly, a 100 ul suspension (4.0 $\log \mathrm{cfu} / \mathrm{ml}$ ) of tested bacteria was used to prepare dilutions. A 20 ul of each bacteria dilution was dropped in duplicate on MHA plates containing bulk cinnamon oil, coarse emulsion and cinnamon oil nanoemulsion. The plates were incubated at $37^{\circ} \mathrm{C}$ for $24 \mathrm{~h}$. Data obtained were analyzed by ANOVA (Analysis of Variance) and the differences between two treatments were evaluated using LSD (Least Significant Difference) test.

\section{RESULTS AND DISCUSSION}

\section{A. Physical and Chemical Properties of Cinnamon Oil}

In this research, the cinnamon oil was analyzed for its physical and chemical properties including cinnamaldehyde content, density, refractive index, optical rotation, and solubility in ethanol $70 \%$ (Table 1).

TABLE I

CHARACTERISTICS OF CinNAMON OIL

\begin{tabular}{|l|c|}
\hline \multicolumn{1}{|c|}{ Characteristics } & Results \\
\hline Cinnamaldehyde content $(\%)$ & 94.58 \\
\hline Density $\left(20^{\circ} \mathrm{C}\right)$ & 1.0425 \\
\hline Refractive index $\left(20^{\circ} \mathrm{C}\right)$ & 1.6157 \\
\hline Optical rotation $\alpha \mathrm{D}$ & $-0.40^{\circ}$ \\
\hline Solubility in ethanol $70 \%(\mathrm{v} / \mathrm{v})$ & $1: 3$ clear \\
\hline
\end{tabular}

The cinnamon oil used in this study is a food grade cinnamon oil and has a $94.88 \%$ cinnamaldehyde chemical component. Cinnamaldehyde is the most significant component in cinnamon oil [2]. In addition, the physicochemical properties of cinnamon oil in this study have complied with European Pharmacopoeia (EP) and flavor and fragrance industry standard quality, with specific gravity ranging from $1.008-1.030$, refractive index of 1.559 -1.595 , optical rotation $\left(-5^{\circ} \mathrm{C}\right)-\left(-0{ }^{\circ} \mathrm{C}\right)$, and $70 \%$ solubility in ethanol is 1: 3 soluble and clear.

\section{B. Characteristic of Cinnamon Oil Coarse Emulsion}

The stability of the emulsion is one of the most important factors to determine what kind of emulsion-based food products can be created. Emulsion stability demonstrates emulsion consistency in which materials included do not tend to merge each other and form a separate layer. A good emulsion has properties that will not turn into layers, not discolored and did not change its consistency during storage [19].

The coarse emulsion of cinnamon oil was prepared using High Shear Homogenizer (HSH). Characterization of the coarse emulsion was conducted by measuring droplet size and the droplet distribution (PDI). The measurement results are presented in Table 2. As can be seen in Table 2, the speed of HSH and the length of homogenization influenced the droplet size and PDI. As the speed and time of homogenization increase the droplet size decreases. The droplets' sizes were in the range of 10.40 to $18.40 \mu \mathrm{m}$. The smallest range was obtained for the coarse emulsion that homogenized at $14000 \mathrm{rpm}$ for 3 minutes. The higher the energy applied in the homogenization process the smaller the droplet size produced [6]. The smaller the emulsion droplet size the more stable the emulsion will be.

TABLE II

DROPLET SiZE AND PDI OF CINNAMON OIL EMULSION AT VARIOUS SPEED AND TIME OF HOMOGENIZATION

\begin{tabular}{|c|c|c|c|}
\hline $\begin{array}{c}\text { Speed } \\
(\mathbf{r p m})\end{array}$ & Time (min) & $\begin{array}{c}\text { Droplet size } \\
(\boldsymbol{\mu m})\end{array}$ & $\begin{array}{c}\text { Polydispersity } \\
\text { index }\end{array}$ \\
\hline 10000 & 1 & $18.40 \pm 0.032^{\mathrm{f}}$ & $0.630 \pm 0.015^{\mathrm{A}}$ \\
\hline 10000 & 2 & $17.74 \pm 0.021^{\mathrm{f}}$ & $0.662 \pm 0.009^{\mathrm{B}}$ \\
\hline 10000 & 3 & $16.42 \pm 0.040^{\mathrm{ef}}$ & $0.682 \pm 0.019^{\mathrm{B}}$ \\
\hline 12000 & 1 & $15.36 \pm 0.045^{\mathrm{de}}$ & $0.727 \pm 0.003^{\mathrm{C}}$ \\
\hline 12000 & 2 & $14.56 \pm 0.036^{\mathrm{cde}}$ & $0.752 \pm 0.019^{\mathrm{CD}}$ \\
\hline 12000 & 3 & $13.44 \pm 0.045^{\mathrm{bcd}}$ & $0.761 \pm 0.022^{\mathrm{D}}$ \\
\hline 14000 & 1 & $12.36 \pm 0.025^{\text {bc }}$ & $0.826 \pm 0.012^{\mathrm{E}}$ \\
\hline 14000 & 2 & $11.34 \pm 0.031^{\mathrm{ab}}$ & $0.839 \pm 0.018^{\mathrm{E}}$ \\
\hline 14000 & 3 & $10.40 \pm 0.031^{\mathrm{a}}$ & $0.901 \pm 0.032^{\mathrm{F}}$ \\
\hline
\end{tabular}

Note: The different superscript letters in the same column inidicate significantly different values $(\mathrm{P}<0.05)$

The polydispersity index (PDI) provides information on the uniformity of an emulsion droplet size. Lower polydispersity index indicates the size of the resulting droplets is relatively uniform. The polydispersity index (PDI) is a measure of the distribution of molecular mass in a particular sample. Small polydispersity index indicates a narrow particle size distribution which means the more uniform particle size. Increasing polydispersity index shows a broad particle size distribution which is seen from the peak area formed from the analysis. Based on Table 2, it can be seen that as the speed and time of homogenization increases, the polydispersity index also increases. The results suggested that homogenization speed of $14000 \mathrm{rpm}$ for 3 minutes was the optimum condition to prepare the cinnamon oil nanoemulsion.

\section{Characteristic of Cinnamon Oil Nanoemulsion}

Nanoemulsions were prepared with 5, 10, 15, 20 and 25\% of a surfactant. Tween 80, non-ionic surfactant with a hydrophilic-lipophilic balance (HLB) of 15 was chosen. Characterizing of cinnamon oil nanoemulsion was conducted by measuring droplets' diameter, distribution of droplet size, and zeta potential. Table 3 shows the increasing of the homogenization pressure and cycles caused the droplet size and polydispersity index to decrease significantly $(\mathrm{P}<0.05)$.

The effect of Tween 80 concentrations on the droplet size and PDI can be seen in Figure 1. The results showed that the concentration of Tween 80 and the number of homogenization cycles influenced the droplet diameter and PDI significantly $(\mathrm{P}<0.05)$. Figure 1 confirms that increasing the surfactant concentration decreasing the droplets' size of cinnamon oil. According to [9], the surfactant can reduce the 
surface tension between oil and water phase as well as decrease the amount of required energy to break up the oil droplets. Therefore the high concentration of surfactant is needed to cover the surface of droplets [6]. High surfactant concentration can reduce the droplet size due to the increment of surfactant adsorption on the interfacial membrane. This condition facilitates the formation of smaller droplet [20]. The smaller the droplets size, the more stable the nanoemulsion.

TABLE III

DROPLET SIZE AND PDI OF CINNAMON OIL NANOEMULSION AT VARIOUS HOMOGENIZATION PRESSURE AND HOMOGENIZATION CYCLES

\begin{tabular}{|c|c|c|c|}
\hline $\begin{array}{c}\text { Homogenization } \\
\text { Pressure (Bar) }\end{array}$ & $\begin{array}{c}\text { Number } \\
\text { of Cycle }\end{array}$ & $\begin{array}{c}\text { Droplet size } \\
\text { (nm) }\end{array}$ & $\begin{array}{c}\text { Polydispersity } \\
\text { index }\end{array}$ \\
\hline 300 & 1 & $457.5 \pm 1.950^{\mathrm{a}}$ & $0.877 \pm 0.017^{\mathrm{A}}$ \\
\hline 300 & 2 & $410.5 \pm 0.833^{\mathrm{b}}$ & $0.680 \pm 0.018^{\mathrm{B}}$ \\
\hline 300 & 3 & $337.3 \pm 1.401^{\mathrm{c}}$ & $0.558 \pm 0.059^{\mathrm{B}}$ \\
\hline 400 & 1 & $264.1 \pm 1.665^{\mathrm{d}}$ & $0.433 \pm 0.009^{\mathrm{C}}$ \\
\hline 400 & 2 & $164.6 \pm 1.562^{\mathrm{e}}$ & $0.349 \pm 0.014^{\mathrm{D}}$ \\
\hline 400 & 3 & $148.1 \pm 1.514^{\mathrm{f}}$ & $0.259 \pm 0.081^{\mathrm{E}}$ \\
\hline 500 & 1 & $133.0 \pm 1.528^{\mathrm{g}}$ & $0.191 \pm 0.042^{\mathrm{F}}$ \\
\hline 500 & 2 & $122.2 \pm 1.473^{\mathrm{h}}$ & $0.163 \pm 0.019^{\mathrm{G}}$ \\
\hline 500 & 3 & $117.5 \pm 0.917^{\mathrm{i}}$ & $0.123 \pm 0.010^{\mathrm{H}}$ \\
\hline
\end{tabular}

Note: The different superscript letters in the same column indicate significantly different values $(\mathrm{P}<0.05)$

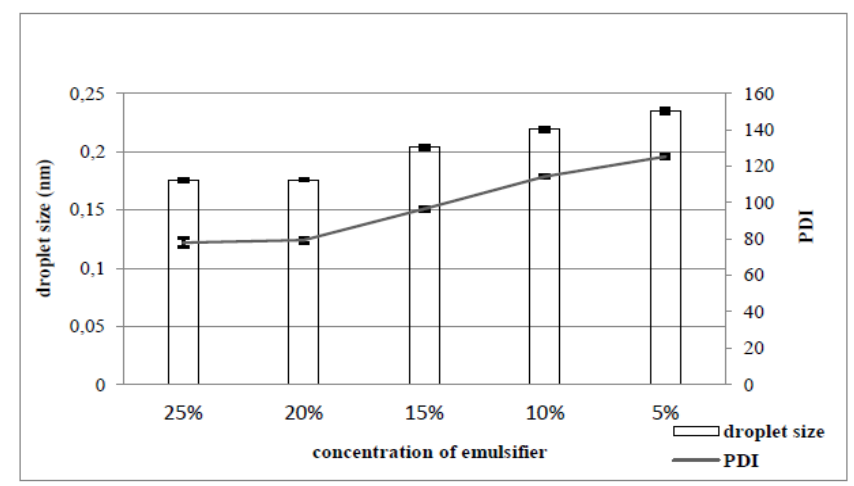

Fig. 1 The droplet size and PDI of cinnamon oil nanoemulsion at various concentrations of Tween 80

The diameter of a cinnamon oil droplet in nanoemulsion system ranging from 111.7 to $151.8 \mathrm{~nm}$. This value indicates that the dispersions are nanoemulsion. Nanoemulsion has droplet size about 50-500 $\mathrm{nm}$ [7]. At a concentration of $25 \%$ tween 80 , the smallest droplet size was achieved, but this was not significantly different with $20 \%$ concentration. Hence $20 \%$ tween 80 was chosen as the optimum concentration to produce cinnamon oil nanoemulsion.

\section{Characteristic of the optimum cinnamon oil nanoemulsion}

Figure 2A shows that the polydispersity index of the cinnamon oil nanoemulsion prepared with the optimum formulation. The polydispersity index was monomodal (only one peak) and the range between 40 to $300 \mathrm{~nm}$. The mean diameter (z-average) of the nanoemulsion droplets was 103.4 $\mathrm{nm}$ with PDI of 117.7. Polydispersity index illustrates the uniformity of the oil droplet size thus the smaller the PDI values indicate, the more uniform of the droplet size. The smaller PDI also means the more uniform of oil droplets distribution. The PDI which is less than 0.2 demonstrates an overview of good uniformity of droplet size.

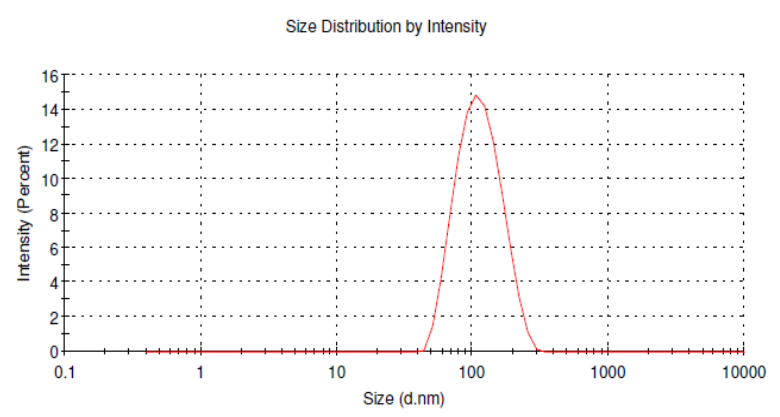

Fig. 2A The distribution of cinnamon oil nanoemulsion droplet size prepared with the optimum formulation

Figure 2B informs the zeta potential of nanoemulsion prepared with the best formulation. Zeta potential is a value that can be used to predict and control the stability of an emulsion system. The stability of an emulsion is good if the value of the zeta potential is more than 30 while if the value is lower than 30 means unstable emulsion. The positive and negative values designate the $\mathrm{pH}$. Positive (+) indicates low $\mathrm{pH}$ (acidic) while negative (-) indicates high pH (alkaline) [21]. The result of zeta potential in this study is monomodal (only one peak), and the range is between $-30 \mathrm{mV}$ to $-55 \mathrm{mV}$. These results indicate that the optimized formulation $(15 \%$ cinnamon oil, $20 \%$ surfactant, homogenized at 500 bars and three cycles) produced stable nanoemulsion with the droplets size in the nanometer range.

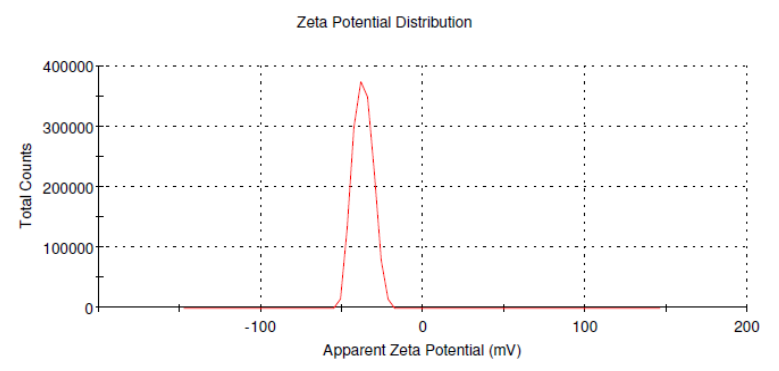

Fig. 2B The profile of zeta potential of cinnamon oil nanoemulsion prepared with the optimized formulation

\section{E. The stability of optimized nanoemulsion during storage}

Emulsion stability is a complex issue and can be influenced by some factors including particle size, viscosity and environmental conditions such as temperature and shear force [22]. The size of the droplets determines nanoemulsion stability. Conversely, the instability characterized by the occurrence of phase separation. The stability can also be affected by the storage temperature. The stability of nanoemulsions in this research was observed during storage at different temperatures.

Table 4 shows the droplet size and PDI of cinnamon oil nanoemulsion prepared with the optimum formulation and stored for ten days. The droplet size of nanoemulsion ranges from $121.0 \pm 0.849 \mathrm{~nm}$ to $121.9 \pm 0.700 \mathrm{~nm}$ and PDI of $0.2323 \pm 0.010$ to $0.143 \pm 0.008$. The results also informed that the droplet size and PDI of each treatment were not significantly different $(\mathrm{P}>0.05)$ between days during storage. This value indicates that the optimum formulation produced stable nanoemulsion. 
TABLE IV

The EFFeCt of Storage on CinNAMON OIL NANOEMUlsion PREPARED WITH THE OPTIMUM FORMULATION

\begin{tabular}{|c|c|c|}
\hline $\begin{array}{c}\text { Storage time } \\
\text { (days) }\end{array}$ & $\begin{array}{c}\text { Droplet size } \\
(\mathbf{n m})\end{array}$ & $\begin{array}{c}\text { Polydispersity } \\
\text { index }\end{array}$ \\
\hline 0 & $121,6 \pm 0.608$ & $0,134 \pm 0.008$ \\
\hline 2 & $121,9 \pm 0.153$ & $0,132 \pm 0.011$ \\
\hline 4 & $121,2 \pm 0.700$ & $0,123 \pm 0.010$ \\
\hline 6 & $121,9 \pm 0.850$ & $0,128 \pm 0.001$ \\
\hline 8 & $121,3 \pm 0.551$ & $0,126 \pm 0.010$ \\
\hline 10 & $121,0 \pm 0.849$ & $0,128 \pm 0.006$ \\
\hline
\end{tabular}

\section{F. Effect of Storage Temperatures on Nanoemulsion} Characteristics

To find out whether the formulation of nanoemulsion can be applied to commercial products, it is imperative to examine the stability for an extended period. The nanoemulsion characteristics were monitored by measuring the droplet size, PDI and zeta potential. The cinnamon oil nanoemulsions for this purpose were stored below $4{ }^{\circ} \mathrm{C} \pm$ $2{ }^{\circ} \mathrm{C}, 28{ }^{\circ} \mathrm{C} \pm 2{ }^{\circ} \mathrm{C}$ and $40{ }^{\circ} \mathrm{C} \pm 2{ }^{\circ} \mathrm{C}$ for 3 months. As can be seen in Table 5 , the results showed that the storage temperatures were not significantly different $(\mathrm{P}>0.05)$ on the droplet size and PDI of cinnamon oil nanoemulsion, but significantly different $(\mathrm{P}<0.05)$ on zeta potential. This revealed that the nanoemulsions were stable for three months at various storage temperatures. Also, zeta potential values were also in a stable range (less than $-30 \mathrm{mV}$ ) during storage.

TABLE V

The PARTICLE Size, PDI AND ZETA Potential of CinNAMON OIL NANOEMULSION DURING STORAGE

\begin{tabular}{|c|c|c|c|c|}
\hline $\begin{array}{c}\text { Temp } \\
\left({ }^{\circ} \mathbf{C}\right)\end{array}$ & $\begin{array}{c}\text { Duration } \\
(\mathbf{d a y s})\end{array}$ & $\begin{array}{c}\text { Droplet Size } \\
(\mathbf{n m})\end{array}$ & PDI & Zeta Potential \\
\hline $4 \pm 2$ & 0 & $121.5 \pm 0.300$ & $0.122 \pm 0.002$ & $-34.0 \pm 0.002^{\mathrm{ABC}}$ \\
\hline $4 \pm 2$ & 30 & $121.9 \pm 0.321$ & $0.129 \pm 0.005$ & $-34.6 \pm 0.005^{\mathrm{BC}}$ \\
\hline $4 \pm 2$ & 60 & $121.2 \pm 0.624$ & $0.125 \pm 0.006$ & $-33.8 \pm 0.006^{\mathrm{AB}}$ \\
\hline $4 \pm 2$ & 90 & $121.3 \pm 0.850$ & $0.104 \pm 0.034$ & $-34.3 \pm 0.034^{\mathrm{BC}}$ \\
\hline $28 \pm 2$ & 0 & $121.9 \pm 0.289$ & $0.125 \pm 0.006$ & $-32.1 \pm 0.006^{\mathrm{A}}$ \\
\hline $28 \pm 2$ & 30 & $121.5 \pm 1.556$ & $0.125 \pm 0.011$ & $-34.8 \pm 0.011^{\mathrm{BC}}$ \\
\hline $28 \pm 2$ & 60 & $121.6 \pm 0.115$ & $0.139 \pm 0.002$ & $-35.9 \pm 0.002^{\mathrm{CD}}$ \\
\hline $28 \pm 2$ & 90 & $122.3 \pm 1.168$ & $0.156 \pm 0.055$ & $-34,2 \pm 0.055^{\mathrm{BC}}$ \\
\hline $40 \pm 2$ & 0 & $122.6 \pm 0.252$ & $0.191 \pm 0.056$ & $-37.1 \pm 0.056^{\mathrm{C}}$ \\
\hline $40 \pm 2$ & 30 & $122.4 \pm 1.414$ & $0.155 \pm 0.057$ & $-33.9 \pm 0.057^{\mathrm{AB}}$ \\
\hline $40 \pm 2$ & 60 & $122.6 \pm 1.320$ & $0.100 \pm 0.031$ & $-33.9 \pm 0.031^{\mathrm{AB}}$ \\
\hline $40 \pm 2$ & 90 & $122.3 \pm 0.862$ & $0.123 \pm 0.005$ & \\
\hline
\end{tabular}

Increasing in emulsion droplet size can be affected by differences in storage temperatures. High storage temperature is closely related to the energy transfer from the environment to the external phase which causes the external phase molecules to gain energy. This energy will move the external phase molecules and cause interfacial tension to rise [23]. Growing the interfacial tension can lower the viscosity thus creating the unstable condition. However, the results of this research do not indicate the increment of droplets size significantly $(\mathrm{P}>0.05)$ during emulsion storage period at different temperatures.

\section{G. Transmission Electron Microscope (TEM) Observation}

Droplet morphology was an important characteristic in an emulsion system. Observation of nanoemulsion droplet morphology was performed using Transmission Electron Microscope (TEM). TEM analysis serves to monitor the surface morphology of emulsion droplet displayed through an image. Based on the characterization by TEM at a magnification of $13500 x$, the droplets of cinnamon oil nanoemulsion have nearly spherical (Fig 3).

TEM analysis was only performed for two samples: a). Nanoemulsion which freshly prepared and b). Nanoemulsion which had been stored for three months at $4{ }^{\circ} \mathrm{C}$. TEM analysis results are shown in Figure $3 \mathrm{~A}$ and $3 \mathrm{~B}$. Figure $3 \mathrm{~A}$ and $3 \mathrm{~B}$ show a relatively rounded form of nanoemulsion droplet. The oil droplet is surrounded by a suspected black circle of surfactant layer which absorbed on the surface of the interfacial membrane. This nanoemulsion droplet is similar to the black layer of protein that is surrounding the oil droplets in [24] studies.

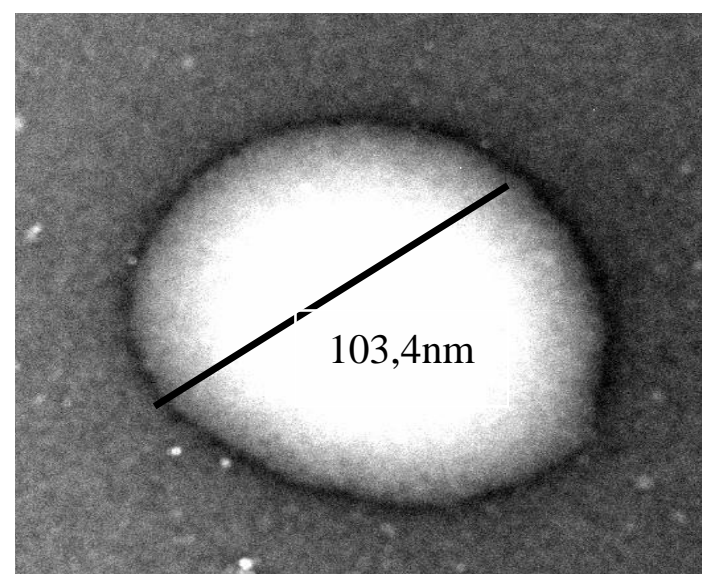

Fig. 3A Freshly prepared emulsion

The TEM analysis results confirm that the droplets' shape and size of the two samples did not differ significantly. A sample of freshly prepared cinnamon oil nanoemulsion has a droplet size of $103.4 \mathrm{~nm}$ (Fig. 3A) and the one after 3 months storage at a temperature of $4{ }^{\circ} \mathrm{C}$ has a diameter of 113.2 nm (Fig. 3B).

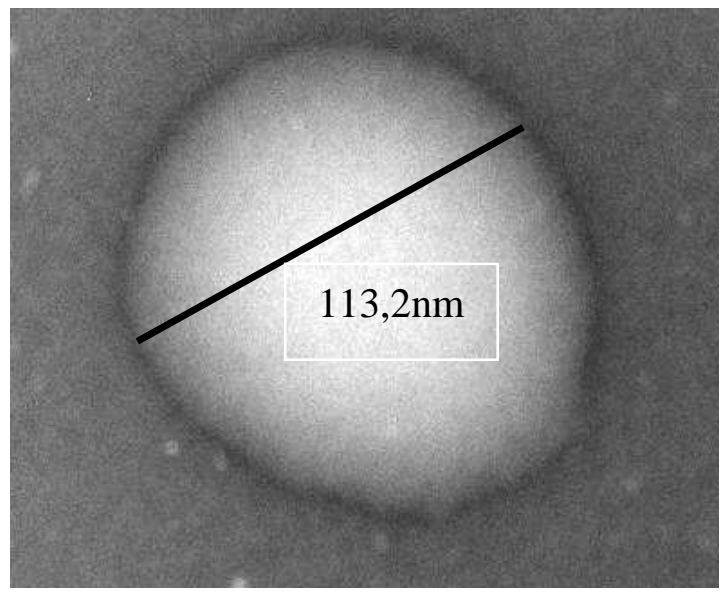

Fig. 3B Droplet after 3 months storage at temperatures $4^{\circ} \mathrm{C}$ 


\section{H. Antibacterial Activity of Cinnamon Oil Nanoemulsions}

The antibacterial activity test of bulk cinnamon oil, coarse emulsion and nanoemulsion conducted against Staphylococcus aureus (Gram-positive) and Escherichia coli (Gram-negative). The concentration of bulk cinnamon oil and coarse emulsion used for antibacterial activity test in this study was similar to the concentration of cinnamon oil nanoemulsion. The results are shown in Table 6. It can be seen that at $1 \%(\mathrm{v} / \mathrm{v})$ concentration, either bulk cinnamon oil, coarse emulsion, and cinnamon oil nanoemulsion has been able to inhibit the growth of $\mathrm{S}$. aureus and $\mathrm{E}$. coli. However, at lower concentrations $(0.25,0.5$ and $0.75 \% \mathrm{v} / \mathrm{v})$ of bulk cinnamon oil, coarse emulsion and cinnamon oil nanoemulsion have no antibacterial on S. aureus and E. coli bacteria. This is similar to the results of antibacterial oil test of anise oil nanoemulsion for S. aureus and E.coli in [25]. Determining the value of MIC (Minimum Inhibitory Concentration) aims to govern the lowest concentration of essential oil which can inhibit the growth of bacteria and characterize by the formation of a clear zone (Table 7).

TABLE VI

THE MINIMUM INHIBITORY CONCENTRATION (MIC) OF BULK CINNAMON OIL, COARSE EMULSION AND NANOEMULSION AGAINST S. AUREUS AND $E$

\begin{tabular}{|c|c|c|c|c|c|c|}
\hline \multirow{3}{*}{ Strain } & \multirow{3}{*}{$\begin{array}{c}\text { Antibacterial } \\
\text { agents }\end{array}$} & \multicolumn{5}{|c|}{ COLI } \\
\hline & & \multicolumn{5}{|c|}{ Concentration $(\%, \mathrm{v} / \mathrm{v})$} \\
\hline & & 2 & 1 & 0.75 & $\mathbf{0 . 5 0}$ & 0.25 \\
\hline \multirow[t]{3}{*}{ E. coli } & $\begin{array}{l}\text { Bulk cinnamon } \\
\text { oil }\end{array}$ & - & - & + & + & + \\
\hline & $\begin{array}{l}\text { Coarse } \\
\text { emulsion }\end{array}$ & - & - & + & + & + \\
\hline & Nanoemulsion & - & - & + & + & + \\
\hline \multirow[t]{3}{*}{$\begin{array}{l}S . \\
\text { aureus }\end{array}$} & $\begin{array}{l}\text { Bulk cinnamon } \\
\text { oil }\end{array}$ & - & - & + & + & + \\
\hline & $\begin{array}{l}\text { Coarse } \\
\text { emulsion }\end{array}$ & - & - & + & + & + \\
\hline & Nanoemulsion & - & - & + & + & + \\
\hline
\end{tabular}

(-) inhibit the growth of S. aureus and E. coli.

(+) no antibacterial on $S$. aureus and E. coli

TABLE VII

THE INHIBITION ZONE DiAMETER OF BULK CINNAMON OIL, COARSE EMULSION AND NANOEMULSION AGAINST S. AUREUS AND E. COLI

\begin{tabular}{|l|l|c|c|}
\hline \multicolumn{1}{|c|}{ Strain } & \multicolumn{1}{|c|}{$\begin{array}{c}\text { Antibacterial } \\
\text { agents }\end{array}$} & \multicolumn{2}{|c|}{ Inhibition zone (mm) } \\
\hline & \multicolumn{1}{|c|}{$2 \%$} & $1 \%$ \\
\hline \multirow{2}{*}{ E. coli } & $\begin{array}{l}\text { Bulk } \\
\text { cinnamon oil }\end{array}$ & 12.26 & 10.74 \\
\cline { 2 - 4 } & Coarse emulsion & 12.18 & 10.60 \\
\cline { 2 - 4 } & Nanoemulsion & 12.22 & 10.76 \\
\hline \multirow{5}{*}{ S. aureus } & $\begin{array}{l}\text { Bulk } \\
\text { cinnamon oil }\end{array}$ & 14.58 & 10.02 \\
\cline { 2 - 4 } & Coarse emulsion & 14.50 & 10.00 \\
\cline { 2 - 4 } & Nanoemulsion & 14.62 & 10.04 \\
\hline
\end{tabular}

The results of cell count after the two bacteria tested at $37{ }^{\circ} \mathrm{C}$ incubation for 24 hours showed that the highest number of bacterial cells was in bulk cinnamon oil, followed by the coarse emulsion and lowest number of bacterial cells was in cinnamon oil nanoemulsion (Table 8). This indicates that cinnamon oil nanoemulsion has a higher antibacterial activity than coarse emulsion and bulk cinnamon oil.
TABLE VIII

The CELl Count of S. AuREuS AND E.COLI TREATED With BulK CINNAMON OIL, COARSE EMULSION AND NANOEMULSION

\begin{tabular}{|l|l|l|}
\hline Strain & Antibacterial agents & $\begin{array}{l}\text { After 24 hour } \\
\text { incubation } \\
\text { (Log cfu/ml) }\end{array}$ \\
\hline S. aureus & Growth control & $9.2 \pm 0.14$ \\
\hline & Bulk cinnamon oil & $5 \pm 0.21$ \\
\hline & Coarse emulsion & $4.7 \pm 0.14$ \\
\hline E. coli & $\begin{array}{l}\text { Cinnamon } \\
\text { nanoemulsion }\end{array}$ & $2.8 \pm 0.28$ \\
\hline & Growth control & $9.6 \pm 0.07$ \\
\hline & Bulk cinnamon oil & $6 \pm 0.14$ \\
\hline & Coarse emulsion & $5 \pm 0.21$ \\
\hline & $\begin{array}{l}\text { Cinnamon } \\
\text { nanoemulsion }\end{array}$ & $4.8 \pm 0.07$ \\
\hline
\end{tabular}

Nanoemulsion obtained by high-pressure homogenization process and the coarse emulsion homogenized by a highshear homogenizer. HPH can produce emulsions with smaller droplet sizes compared to high-shear homogenization process. The smaller the droplet sizes, the more easily the active components of cinnamon oil to penetrate the bacterial cell membrane. This condition increases inhibition to the growth of bacteria. The results obtained are by the finding of Herigstag et al. [18] that confirmed the delivery of antibacterial components in nanoemulsion happened faster than in the coarse emulsion due to smaller droplet sizes and a broader exposed to the surface of bacterial cells.

\section{CONCLUSIONS}

Optimized nanoemulsification process with $20 \%$ concentrations of Tween 80 and 3 cycles of homogenization process using high-pressure homogenizer at 500 bars produced cinnamon oil nanoemulsion with droplet diameter $\pm 117.5 \mathrm{~nm}$ and polydispersity index (PDI) of 0.123 . Cinnamon oil nanoemulsions stored at different temperatures had droplet sizes that were not statistically different $(\mathrm{P}>0.05)$.

The bulk cinnamon oil, coarse emulsion and cinnamon oil nanoemulsion have the same minimum concentration of inhibition against $S$. aureus and $E$. coli, but the nanoemulsion has the lowest number of cells count compared to bulk cinnamon oil and coarse emulsion after incubation at $37{ }^{\circ} \mathrm{C}$ for 24 hours. Antibacterial activity test indicated that cinnamon oil nanoemulsion showed better antibacterial activity compared to the coarse emulsion and bulk cinnamon oil.

\section{ACKNOWLEDGMENT}

The authors thank the Ministry of Research, Technology and Higher Education of The Republic of Indonesia for funding this research through Research Institution of Syiah Kuala University.

\section{REFERENCES}

[1] Rao, J., and McClements, D.J., Food-grade microemulsions, nanoemulsions, and emulsions: Fabrication from sucrose monopalmitate and lemon oil, Food Hydrocolloids, vol. 25:, 14131423, 2011.

[2] Hoque, Md. M., Bari, M.L., Juneja, V.K., and Kawamoto, S., Antimicrobial Activity of Cloves and Cinnamon Extracts against 
Food Borne Pathogens and Spoilage bacteria, and Inactivation of Listeria monocytogenes in Ground Chicken meat with their Essential oils, Report of The National Food Research Institute vol. 72: 9- 21, 2008.

[3] Zouheyr, H., Allen, R., and Marin, G. P., Effect of Essential oil of Cinnamomum zeylanicum on some Pathogenic Bacteria. African Journal of Microbiology Research vol. 8 (10): 1026-1031, 2014.

[4] Nabavi, S.F., Arianna, D.L., Morteza, I., Eduardo, S.S., and Maria, Antibacterial Effects of Cinnamon: From Farm to Food, Cosmetic and Pharmaceutical Industries, Nutrients vol 7: 7729-7748, 2015.

[5] Knobloch, K., Weigand, H., Weis, N., Schwarm, H.M., and Vigenschow, H., Action of terpenoids on energy metabolism. In: Brunke, E.J. (Ed.), Progress in Essential Oil Research: 16th International Symposium on Essential Oils. De Gruyter: 429- 445, 1986.

[6] Affandi, M.M.M., Julian, T., and Majeed, A., Development, and Stability Evaluation of Astaxanthin Nanoemulsion, Asian Journal of Pharmaceutical and Clinical Research, vol 4: 142-148, 2011.

[7] Solans, C., Izquierdo, P., Nolla, J., Azemar, N., and Garcia-Celma, M.J., "Nanoemulsions. Current Opinion in Colloid and Interface Science": vol 10: 102-110, 2005.

[8] Setya, S., Talegaonkar, S., and Razdan, B. K., Nanoemulsions: Formulation Methods and Stability Aspects. 3: 2214 - 2228, 2014.

[9] Eccleston, J., Microemulsions, in J, Swarbrick, J.C. Boylan (Eds), Encyclopedia of Pharmaceutical Technology, NewYork; Marcel Dekker. 375-421, 1994.

[10] Shakeel, F., Baboota, S., Ahuja, A., Ali, J., Faisal, M.S., and Shafiq, S., Stability evaluation of celecoxib nanoemulsion containing tween 80, Thailand Journal Pharmaceutical Science vol. 32: 4-9, 2008.

[11] Mason, T. G., Wilkins, J. N., Nelson, K., Chang, C. B., and Graves, S. M., "Nanoemulsions: Formation, Structure, and Physical Properties.'Journal of Physics: Condensed Matter Journal of Physics: Condensed Matter ., vol. 18: pp. 635- 666, 2006.

[12] Amaral, D. M.F., and Bhargava, K., "Essential Oil Nanoemulsions and Food Applications," Advances in Food Technology and Nutritional Sciences Open Journal: pp. 84-86, 2015.

[13] Ziani, K., Chang, Y. H., McLandsborough, L., and McClements, D. J., "Influence of surfactant charge on antimicrobial efficacy of surfactant-stabilized thyme oil nanoemulsions," Journal of Agricultural and Food Chemistry, vol 59 (11):, pp. 6247-6255, 2011.

[14] Mosayeb, A., and Abedini, R., The Effect of Non-Ionic Surfactants on The Interfacial Tension between Crude Oil and Water, Petroleum and Coal, vol. 54 (2): 110-113, 2012.
[15] Bayrak, Y., and Iscan. M., "Studies on The Phase Behaviour of The System Non-Ionic Surfactants/Alcohol/Alkaline/H2O". Colloids and Surfaces Colloids and Surfaces, vol. 268: 99 - 103, 2005.

[16] Donsi, F., M. Annunziata., M. Sessa., and G. Ferrari., Nanoencapsulation of essential oils to enhance their antimicrobial activity in foods". LWT - Food Science and Technology, vol. 44: pp. 1908-1914, 2011.

[17] Ghosh, V., Mukherjee, A., and Chandrasekaran, N., Eugenol-loaded antimicrobial nanoemulsion preserves fruit juice against, microbial spoilage. Colloids and Surfaces B: Biointerfaces Colloids and Surfaces B: Biointerfaces, vol. 114: 392-397, 2013.

[18] Herigstad, B., Hamilton, M., and Heersink, J., How to optimize the drop plate method for enumerating bacteria. Journal of Microbiological Methods, 44: 121-129, 2001.

[19] Flanagan, J. and Singh, H., "Microemulsions: a potential delivery system for bioactive in food." Critical Reviews in Food Science and Nutrition, vol. 4: pp. 221-237, 2006.

[20] Yuan, Y., Gao, Y., Zhao, J., and Mao, L., "Characterization and stability evaluation of B-carotene nanoemulsions prepared by highpressure homogenization under various emulsifying conditions.' Food Research International, vol. 41: pp. 61-68, 2008.

[21] Tan, C. P., and Nakajima, M., " $\beta$-Carotene nanodispersions: Preparation, characterization and stability evaluation," Food Chemistry, vol. 92: pp. 661-671, 2005.

[22] Ben, E.S., Suari, M., Chalid, T.C., and Yulianto, T., "Optimasi Nanoemulsi Minyak Kelapa Sawit (Palm Oil) Menggunakan Sukrosa Monoester". Prosiding Seminar Nasional Perkembangan Terkini Sains Farmasi dan Klinik III:, pp. 31-62, 2013.

[23] McClements, D.J., and Rao, J., "Food-grade nanoemulsions: formulation, fabrication, properties, performance, biological fate, and potential toxicity". Critical Reviews in Food Science and Nutrition, vol. 51:, pp. 285- 330, 2011.

[24] Fernandez-Avila, C., and Trujillo A.J., "Ultra-high pressure homogenization improves oxidative stability and interfacial properties of soy protein isolate-stabilized emulsions." Food ChemistryChem, vol. 209: pp. 104-113, 2016.

[25] Shinoda K, and Saito H., "The Stability of O/W Type Emulsions as Functions of Temperature and the HLB of Emulsifiers: The Emulsification by PIT method." Journal of Colloid and Interface Science, vol. 30: pp. 258-263. Department of Chemistry, Yokohama National University, Japan, 1969. 